\title{
The role of psychological ownership in retaining talent: A systematic literature review
}

\author{
Authors: \\ Chantal Olckers ${ }^{1}$ \\ Yvonne du Plessis ${ }^{1}$ \\ Affiliations: \\ ${ }^{1}$ Department of Human \\ Resource Management, \\ University of Pretoria, \\ South Africa \\ Correspondence to: \\ Chantal Olckers \\ Email: \\ chantal.olckers@up.ac.za \\ Postal address: \\ Private bag X20, Hatfield \\ 0028, South Africa \\ Dates: \\ Received: 29 Sept. 2011 \\ Accepted: 03 Apr. 2012 \\ Published: 06 Sept. 2012 \\ How to cite this article: \\ Olckers, C., \& Du Plessis, \\ Y. (2012). The role of \\ psychological ownership in \\ retaining talent: A systematic \\ literature review. SA \\ Journal of Human Resource \\ Management/SA Tydskrif vir \\ Menslikehulpbronbestuur, \\ 10(2), Art. \#415, 18 pages. \\ http://dx.doi.org/10.4102/ \\ sajhrm.v10i2.415
}

C 2012. The Authors.

Licensee: AOSIS

OpenJournals. This work

is licensed under the

Creative Commons

Attribution License.
Orientation: Managing psychological ownership can have positive attitudinal and behavioural effects, promote organisational effectiveness and support talent retention.

Research purpose: This paper seeks to explore and describe psychological ownership, distinguish it from other work-related attitudes and clarify the role that psychological ownership can play in retaining talent.

Motivation for the study: Previous studies of human resource practices and organisational characteristics that affect organisational commitment and the retention of talent have reported that absent variables could be responsible for varied results. Psychological ownership could be one of them.

Research design, approach and method: Based on a systematic review of the literature published over the last 20 years, the authors synthesised various research perspectives into a framework of psychological ownership and its links to retaining talent.

Main findings: The authors found that psychological ownership was a comprehensive multidimensional construct. It is distinct from other work-related attitudes and seems capable of enabling organisations to retain the talents of skilled employees.

Practical/managerial implications: Organisations can benefit from psychological ownership because it leads employees to feel responsible towards targets (like organisations) and to show stewardship. It can help organisations to retain talent and influence the intentions of skilled employees to remain with their organisations.

Contribution/value-add: Psychological ownership, as an integrated multidimensional construct, has expanded the existing theory about the organisational commitment and workrelated attitudes that organisations need to retain talent in the 21st century.

\section{Introduction}

\section{Key focus of the study}

Psychological ownership has recently received attention from many researchers. They hypothesise that formal ownership can have positive attitudinal and behavioural effects through psychologically experienced ownership and that a psychological sense of ownership may form integral parts of employees' relationships with their organisations. They suggest that psychological ownership amongst members of organisations can have positive effects on organisational effectiveness and can promote staff retention. Psychological ownership is a situation where employees feel as though the object of ownership, or a piece of it, belongs to them ('It is mine!').

The present study aims, firstly, to explore the literature and describe psychological ownership and its defining elements, because the phenomenon has links with positive behavioural and social-psychological consequences. Secondly, it aims to examine how psychological ownership is distinct from other related constructs. Thirdly, it aims to explore the role that psychological ownership can play in retaining the talents of skilled employees.

\section{Background to the study}

To compete in today's highly competitive business market (Arnold \& Randall, 2010), organisations must recruit top talent and retain talented employees who have psychological connections with their work and organisations. Locally and internationally, skilled employees can choose from a larger pool of jobs in the contemporary world of work. As the 'war for skilled talent' escalates, according to De Villiers (2006), it becomes increasingly important to explore the psychological factors that influence employees' commitment and loyalty so that organisations can retain their skilled employees. 
In 2002, the Hay Group conducted a survey amongst employees who worked in 330 companies in 50 countries. One third of them reported that they intended to resign from their jobs within the next two years (Hay, 2002). Many of the world's most admired companies acknowledge that they will lose half their senior executives in the next five years.

Human Capital at Deloitte conducted research amongst a wide range of companies across all industry sectors in South Africa and published it in The South African guide to executive remuneration and reward. It showed that South African businesses lose up to $50 \%$ of their executives every four to five years (Rich stay comfortably rich, 2008). More than a third (35\%) of executives gave better employment opportunities as their reason for leaving their present organisations (Rich stay comfortably rich, 2008). Therefore, organisations have to face the major challenge of retaining their best and most talented staff. Employee turnover, especially in difficult economic times, can drain the intellectual capital of organisations badly. Furthermore, increasing job mobility in the global knowledge economy, where employees average six employers in a career (O'Neal, 2005), exacerbate the retention challenge.

\section{Trends from the research literature}

Based on a study of human resource practices and other organisational characteristics that affect organisational commitment, Fiorito, Bozeman, Young and Meurs (2007) suggest that psychological ownership may be one of the variables that can serve as a predictor of organisational commitment.

In their development of a model of employee ownership, Pierce, Rubenfeld and Morgan (1991) posit that employee ownership leads to social-psychological and behavioural outcomes. However, in her study of the employee attitudes of 37 Employee Stock Ownership Plan (ESOP) companies, Klein (1987) found no significant relationship between the percentage of stock that the ESOP employees owned and their levels of job satisfaction or commitment. Pendleton, Wilson and Wright (1998) found that most ESOP shareholders did not seem to have a strong sense of ownership and most believed that nothing had changed in the organisation because of employee ownership. In a longitudinal study, Dunn, Richardson and Dewe (1991) found little difference between the attitudes of owners and those of non-owners. In one of the two firms in his case study, Kruse (1984) actually found evidence of lower levels of commitment over time. Long (1982) found a significant decrease in employee satisfaction following a conversion to employee ownership.

These findings suggest that, if actual ownership remains unchanged between the two points of investigation, some mediating and/or extraneous variable other than ownership must be driving attitudinal change. Pierce et al. (1991) have identified an intervening variable, 'psychological ownership', which could play a role in the interface between share ownership and employee commitment.
In later work, Pierce, Kostova and Dirks $(2001,2003)$ drew on studies in sociology, philosophy, human development and psychology to introduce a theory of psychological ownership in organisations. It defined psychological ownership as a construct that is separate and distinct from the legal or equity ownership of an organisation. Mattila and Ikävalko (2003) argue that ownership connects to the relationships between human beings and the things and objects with which they surround themselves. This shows that ownership is a much broader concept than a particular legal regime and the status that follows it. Pierce et al. (1991) suggest that ownership is multidimensional and that it functions as a formal (objective) and as a psychologically experienced phenomenon.

Pierce et al. (1991) suggest that, regardless of the type of ownership (social ownership, worker-producer cooperatives, direct ownership and ESOPs), psychological ownership will lead to the integration of the employee-owner with the organisation and the ownership experience. O'Reilly (2002) notes that:

when managers talk about ownership, what they typically want to instil is not financial ownership but psychological ownership - a feeling on the part of the employees that they have a responsibility to make decisions that are in the long-term interest of the company. (p. 19)

Therefore, Pierce et al. (2001) suggest that, if ESOP employees feel a greater sense of ownership, their commitment to their organisations is likely to increase. Conversely, if they do not experience psychological ownership, their level of organisational commitment is likely to remain unchanged, whatever their level of share ownership.

Therefore, it is important to have a closer look at the mediating and/or extraneous variable of psychological ownership because it is associated with positive behavioural and social-psychological consequences.

\section{Research objectives}

The study had the objectives that follow:

- to explore and describe psychological ownership and its defining elements because it has associations with positive behavioural and social-psychological consequences

- to distinguish psychological ownership from other work-related attitudes (like organisational commitment, organisational identification, internalisation, psychological empowerment and job involvement)

- to explore the role that psychological ownership could play in retaining skilled talent.

\section{Potential value of the study}

The study aims to expand on the existing theory of organisational commitment and the work-related attitudes that organisations need to retain talent by presenting a multidimensional framework of psychological ownership that distinguishes psychological ownership from its antecedent and consequent conditions. It intends to show how organisations can benefit from psychological ownership 
because psychological ownership can lead employees to feel responsible towards targets (like organisations) and to display stewardship. Furthermore, this ownership could play a role in retaining talent and could influence employees' intentions to remain with their organisations.

\section{Research design Research approach}

The researchers conducted a systematic review of the literature. According to Tranfield, Denyer and Smart (2003), a systematic review identifies the key scientific contributions relevant to a subject by using extensive literature searches of published and unpublished studies. By using transparent and reproducible procedures, systematic reviews improve the quality and outcomes of review processes.

Review processes generally consist of three parts: data collection, data analysis and synthesis. In this study, the authors conducted a critical analysis of the work of seminal authors in order to explore and describe psychological ownership and its defining elements, to distinguish psychological ownership from other work-related attitudes and to explore the role that psychological ownership can play in retaining talent.

\section{Research method}

\section{Location of the data}

In this study, the systematic approach entailed extensive searches of relevant management databases. These were EBSCOhost, JSTOR, Business Source Premier, ProQuest, SAGE and InterScience. The authors used these databases because they contain comprehensive data from accredited international and national multidisciplinary journals that specialise in human resource management, social, personnel and applied psychology as well as general management and organisational behaviour - the disciplines within which this research study resides. The authors conducted manual searches as well as Internet searches to identify secondary references and other publications of the researchers the authors identified in their original searches.

\section{Search terms and selected criteria}

In order to explore and describe psychological ownership, the authors used the key words psychological ownership in their literature search. They limited their search to English language publications between 1991 and 2010 that dealt specifically with psychological ownership.

They chose 1991 as the starting date because the first scientific article that they could find that referred to the concept of 'psychological ownership' appeared in that year.

The original search identified more than 67 scientific papers, unpublished conference papers and reviews of the literature. However, the authors chose only published scholarly journals that defined psychological ownership and examined psychological ownership in an organisational context. This resulted in 12 articles.

In order to distinguish psychological ownership from other work-related attitudes, the authors used these keywords: commitment, empowerment, identification, internalisation and job involvement. It is important to note that the search for commitment alone identified more than one million papers, commentaries and literature reviews. However, the focus of the study was to conceptualise psychological ownership and to distinguish it from related concepts. Therefore, the authors chose only the articles, published between 1987 and 2010, that enabled them to define the core of the concepts (commitment, empowerment, identification, internalisation and job involvement), that gave the motivational basis of the concepts, that discuss the psychological state of the concepts and indicate the consequences of particular concepts. The search on work-related attitudes resulted in 13 papers.

To explore the role that psychological ownership can play in retaining talent, the authors initially used these keywords in their literature search: talent, retaining talent, talent retention, retention to stay and employee retention. They conducted this search to define the concept of talent and to highlight the importance of retaining talent for organisations. Of the 14 scientific articles that were relevant to this study and were written between 2000 and 2010, eight remained. The authors eliminated five articles because they were not relevant to the purpose of the study. The authors then used combinations of the key words talent, retaining talent, talent retention, retention to stay and employee retention with the key words psychological ownership. This search resulted in only one published paper for more detailed scrutiny from 10 citations. However, this one article did not focus specifically on retaining talent, but on psychological ownership as a predictor of intentions to leave.

Table 1 contains the list of all the journals from which the authors sampled the 34 articles in this study.

\section{Analysis and presentation of the data}

The authors used thematic analysis for analysing and reporting. This, according to Tranfield et al. (2003), summarises what one knows already and focuses on the extent to which there is consensus across various themes.

The authors evaluated the articles in terms of:

- the purposes of the studies

- whether they were qualitative or quantitative

- their methods of collecting data

- their key findings.

The authors categorised common themes that emerged from the data to achieve the three objectives of the study: to explore and describe psychological ownership and its defining elements, to distinguish psychological ownership from other work-related attitudes and to explore the role that psychological ownership could play in retaining talent. 
TABLE 1: Articles used in the review.

\begin{tabular}{|c|c|c|c|}
\hline Publisher & Journal name & Online ISSN number & Frequency \\
\hline \multirow[t]{4}{*}{ Elsevier } & Human Resource Management Review & $1873-7889$ & 1 \\
\hline & Journal of Vocational Behavior & $1095-9084$ & 1 \\
\hline & Academy of Management Review & $1930-3807$ & 3 \\
\hline & Academy of Management Journal & 1948-0989 & 1 \\
\hline SAGE Publications & Educational and Psychological Measurement & $1552-3888$ & 1 \\
\hline Psycnet & Review of General Psychology & - & 1 \\
\hline Taylor \& Francis Group & Journal of Social Psychology & $1940-1183$ & 2 \\
\hline American Psychological Association & Journal of Applied Psychology & 1939-1854 & 2 \\
\hline Business Perspectives & Problems and Perspectives in Management & $1810-5467$ & 1 \\
\hline Development Dimensions International & HR Benchmark Group & - & 1 \\
\hline \multirow[t]{4}{*}{ Wiley-Blackwell } & Journal of Organizational Behavior & 1099-1379 & 4 \\
\hline & International Journal of Management Review & $1460-8545$ & 1 \\
\hline & Personnel Psychology & $1744-6570$ & 1 \\
\hline & Journal of Management Studies & $1467-6486$ & 1 \\
\hline Johnson Graduate School of Management & Administrative Science Quarterly & - & 1 \\
\hline ProQuest & Group and Organizational Studies & $0364-1082$ & 1 \\
\hline Emerald & Career Development International & $1362-0436$ & 1 \\
\hline Springer Science & Journal of Business Ethics & $1573-0697$ & 1 \\
\hline Harvard Business School Public Corporation & Harvard Business Review & $0017-8012$ & 1 \\
\hline Financial Management Institute & Financial Management Institute Journal & - & 1 \\
\hline Academy of Management & Academy of Management Executive & $1079-5545$ & 1 \\
\hline American Society for Training and Development & Training and Development & $1055-9760$ & 1 \\
\hline Association of Professional Managers in South Africa & South African Journal of Business Management & 0378-9098 & 1 \\
\hline Thavan International journals & KKIMRC International Journal of Research in Finance and Accounting & - & 1 \\
\hline \multirow[t]{2}{*}{ AOSIS Open Journals } & South African Journal of Human Resource Management & $2071-078 x$ & 1 \\
\hline & South African Journal of Industrial Psychology & 2071-0768 & 2 \\
\hline
\end{tabular}

Tables 2, Table 3 and Table 5 summarise the key features of the papers the authors used for this study.

\section{Results}

\section{Study objective 1: To define and explain psychological ownership}

Research on the psychology of possession links feelings of ownership with positive attitudes about the targets of ownership, self-concept and a sense of responsibility to the targets. Pierce et al. (2001) conclude that:

- the feeling of ownership is innately human

- employees develop feelings of ownership of both tangible and intangible objects

- ownership has important emotional, behavioural and attitudinal consequences for those who experience it.

Many researchers and scholars have recognised and commented on the relationship between a sense of possession on the one hand and work and organisational contexts on the other. Brown (1989) suggests that psychological ownership may be a key to organisational competitiveness in the 21st century, whereas Kubzansky and Druskat (1993, cited in Pierce et al., 2003), propose that psychological senses of ownership may be integral parts of employees' relationships with their organisations. What is psychological ownership and how can one define it?

Pierce et al. (2003, p. 86) link feelings of possession with a sense of ownership. They define psychological ownership as that state where an individual feels as though the target of ownership or a piece of that target is "theirs"'. In their discussion of the construct, they highlight a number of distinguishing features.

\section{The concept of 'mine'}

Firstly, they suggest that a sense of ownership manifests in the meanings and emotions one usually associates with ' $m y^{\prime}$ or 'mine' and 'our'. The conceptual core of psychological ownership is a feeling of possessiveness (Wilpert, 1989) and of having a psychological link with specific objects or targets (the products of one's labour, one's home, one's country or others). Therefore, psychological ownership answers the question: 'What do I feel is mine?'

\section{Relationship with targets}

Secondly, psychological ownership reflects a relationship between employees and targets: objects that can be either material (like work or tools) or immaterial (like workspace or ideas). In this relationship, employees see the objects as having close connections with themselves, becoming parts of the 'extended self'. Isaacs (1933, p. 225) explains that 'what is mine becomes a part of $m e^{\prime}$.

\section{The cognitive and affective core}

Thirdly, Pierce et al. (2003) have noticed that psychological ownership (the feeling that things are 'mine' or 'ours') has many facets. It includes a cognitive and affective core, as the model in Figure 1 shows. The cognitive aspect reflects employees' awareness, beliefs and thoughts about the targets of ownership. Affectively, feelings of ownership produce pleasure and give the owners feelings of efficacy 
TABLE 2: Psychological ownership.

\begin{tabular}{|c|c|c|c|c|}
\hline Authors & Title & Purposes & Methods & Key findings \\
\hline \multicolumn{5}{|c|}{ Defining psychological ownership, identifying the motives ('roots') of, and 'routes' to, psychological ownership } \\
\hline $\begin{array}{l}\text { Pierce, J.L., Kostova, T., \& } \\
\text { Dirks K.T. (2003) }\end{array}$ & $\begin{array}{l}\text { - The state of } \\
\text { psychological } \\
\text { ownership: Integrating } \\
\text { and extending a century } \\
\text { of research. }\end{array}$ & $\begin{array}{l}\text { - To define psychological ownership, } \\
\text { identify its motives ('roots') and the } \\
\text { 'routes' through which it develops. } \\
\text { - To determine the factors that influence } \\
\text { psychological ownership. } \\
\text { - To propose the positive and negative } \\
\text { consequences of psychological } \\
\text { ownership. }\end{array}$ & $\begin{array}{l}\text { - Qualitative } \\
\text { - Review of the } \\
\text { literature }\end{array}$ & $\begin{array}{l}\text { - The conceptual core of psychological ownership } \\
\text { is a sense of possessing a particular target. } \\
\text { - Psychological ownership reflects a relationship } \\
\text { between a person and an object. } \\
\text { - Psychological ownership comprises a cognitive } \\
\text { and effective core. } \\
\text { - 'Roots' refer to efficacy and effectance, self- } \\
\text { identity and having a place. } \\
\text { - 'Routes' refer to controlling targets, intimately } \\
\text { knowing them and investing the self in targets. } \\
\text { - Factors are targets, employees, processes and } \\
\text { contextual factors. } \\
\text { - The positive consequences are citizenship, } \\
\text { personal sacrifice and assumption of risk, } \\
\text { experienced responsibility and stewardship. } \\
\text { - The negative consequences are unwillingness to } \\
\text { share and deviant behaviours. }\end{array}$ \\
\hline $\begin{array}{l}\text { Pierce, J.L., Kostova, T., \& } \\
\text { Dirks, K.T. (2001) }\end{array}$ & $\begin{array}{l}\text { - Towards a theory of } \\
\text { psychological ownership } \\
\text { in organizations. }\end{array}$ & $\begin{array}{l}\text { - To define psychological ownership, } \\
\text { identify its motives ('roots') and 'routes' } \\
\text { through which it develops and to } \\
\text { propose organisational outcomes. } \\
\text { - To determine the distinctiveness of } \\
\text { psychological ownership from other } \\
\text { related constructs. }\end{array}$ & $\begin{array}{l}\text { - Qualitative } \\
\text { - Review of the } \\
\text { literature }\end{array}$ & $\begin{array}{l}\text { - Psychological ownership is a state in which } \\
\text { employees feel as though the target of } \\
\text { ownership is 'his or hers'. } \\
\text { - Its 'roots' are efficacy and effectance, self- } \\
\text { identity and having a place. } \\
\text { - Its 'routes' are to control targets, intimately } \\
\text { knowledge of targets and investing the self in } \\
\text { targets. } \\
\text { - The organisational outcomes are felt } \\
\text { responsibility, stewardship and altruistic } \\
\text { behaviours. } \\
\text { - Psychological ownership is distinct from } \\
\text { commitment, identification and internalisation. }\end{array}$ \\
\hline
\end{tabular}

\section{Different forms of psychological ownership}

Avey, J.B., Avolio, B.J., Crossley, C.D., \& Luthans, F. (2009)

- Psychological ownership: Theoretical extensions, measurement and relation to work outcomes.

Types of psychological ownership

Mayhew, M.G., Ashkanasy, - A study of the

N.M., Bramble, T, \&

Gardner, J. (2007) antecedents and consequences of
psychological ownership in organizational settings.
- To investigate the components of psychological ownership and to compile a measurement.
- Quantitative Questionnaire development

Psychological ownership has two forms :

- Promotion-orientated psychological ownership consists of four dimensions: self-efficacy, accountability, sense of belongingness and self-identity.

- Prevention-orientated psychological ownership has one dimension: territoriality.

- To investigate whether psychological ownership is distinct from the work attitudes of organisational commitment and job satisfaction.

- To determine the effect of autonomy as an antecedent to psychological ownership.

To determine the consequences of psychological ownership.

\section{Factors influencing the emergence of psychological ownership}

Pierce, J.L., Jussila, I., \& Cummings, A. (2009)

- Psychological ownership

Pierce, J.L., O'Driscoll, M.P., - Work environment \& Coghlan, A.M. (2004)

\section{Consequences of psychological ownership}

Buchko, A.A. (1993)

O’Driscoll, M.P., Pierce, J.L., \& Cochlan, A. (2006)

\section{- The psychology of}

Olzer, H., Yilmaz, A. \& Ozler, - Psychological A. (2008) within the job design context: Revision of the job characteristics model. structure and psychological ownership: The mediating effects of control.

- The effects of employee ownership on employee attitudes: An integrated causal model and path analysis. ownership: Work environment structure, organizational commitment, and citizenship behaviors.

- To determine the connection between job design and psychological ownership.

$\begin{array}{ll}\text { - Exploring contextual factors that may } & \text { - Quantitative } \\ \text { lead to the development of psychological } & \text { - Supervisory } \\ \text { ownership in work settings. } & \text { report data and } \\ & \text { self-reports }\end{array}$

- To test a model of the effect of employe ownership on employee attitudes and behaviours.

- To explore the mediating role of psychological ownership (of jobs and organisations) in the relationship between levels of work environment structure and employee responses.

- To examine whether organisational climate, job satisfaction and ownership: An empirical study on its antecedents and impacts upon organizational behaviours. foctors affect ownership.

- To examine the extent to which psychological ownership influences organisational citizenship behaviours and organisational commitment.
Quantitative

- Organisation-based and job-based psychological ownership are distinct work attitudes.

- Psychological ownership predicts job satisfaction and organisational commitment and mediates and organisational commitment and mediates work attitudes.
- Qualitative - Theoretical modification of the Hackman and Oldham Job Characteristics Model

- Psychological ownership is a plausible substitute for other proposed mediating psychological states in the job design-employee response relationship.

- Experienced control mediates the relationship between three sources of work environment structure - technology, autonomy and participative decision-making - and psychological ownership of jobs and organisations.

- Quantitative - Questionnaires

- Perceived influence of ownership has a positive relationship with job satisfaction and organisational commitment.

- Job satisfaction and organisational commitment have negative relationships with intentions to leave.

Quantitative - Questionnaires

- Self-ratings

Pychological ownership mediates the relationship of work environment structure with employee citizenship behaviours and organisational commitment.

- Psychological ownership links to, but is not completely redundant in terms of, affective organisational commitment.

- Quantitative

- Questionnaires

- Job satisfaction and a participative organisational climate strengthen the feelings of ownership of employees.

- The longer employees work in organisations, the more ownership they feel towards their organisations.

- Psychological ownership increases organisational citizenship behaviours and organisational commitment.

Note: Please see the full reference list of the article, Olckers, C. \& Du Plessis, Y. (2012). The role of psychological ownership in retaining talent: A systematic literature review. SA Journal of Human Resource Management/SA Tydskrif vir Menslikehulpbronbestuur, 10(2), Art. \#415, 18 pages. http://dx.doi.org/10.4102/sajhrm.v10i2.415 
TABLE 2 (Continues...): Psychological ownership.

\begin{tabular}{|c|c|c|c|c|}
\hline Authors & Title & Purposes & Methods & Key findings \\
\hline \multicolumn{5}{|c|}{ Consequences of psychological ownership } \\
\hline $\begin{array}{l}\text { VandeWalle, D., Van Dyne, } \\
\text { L., \& Kostova, T. (1995) }\end{array}$ & $\begin{array}{l}\text { - Psychological } \\
\text { ownership: An empirical } \\
\text { examination of its } \\
\text { consequences. }\end{array}$ & $\begin{array}{l}\text { - To determine the consequences of } \\
\text { psychological ownership. }\end{array}$ & $\begin{array}{l}\text { - Quantitative } \\
\text { - Questionnaires }\end{array}$ & $\begin{array}{l}\text { - Psychological ownership has a positive } \\
\text { relationship with extra-role behaviour. } \\
\text { - Organisational commitment mediates the } \\
\text { effects of psychological ownership on extra-role } \\
\text { behaviour. } \\
\text { - Psychological ownership predicts extra-role } \\
\text { behaviour better. }\end{array}$ \\
\hline $\begin{array}{l}\text { Van Dyne, L., \& Pierce, J.L. } \\
\text { (2004) }\end{array}$ & $\begin{array}{l}\text { - Psychological ownership } \\
\text { and feelings of } \\
\text { possession: Three } \\
\text { field studies predicting } \\
\text { employee attitudes } \\
\text { and organizational } \\
\text { citizenship behaviors. }\end{array}$ & $\begin{array}{l}\text { - To examine the relationships of } \\
\text { psychological ownership with work } \\
\text { attitudes and behaviours. }\end{array}$ & $\begin{array}{l}\text { - Quantitative } \\
\text { - Questionnaires }\end{array}$ & $\begin{array}{l}\text { - Psychological ownership increases the ability } \\
\text { to predict organisation-based self-esteem } \\
\text { and organisational citizenship behaviour in } \\
\text { organisations and goes beyond demographic } \\
\text { characteristics, commitment and satisfaction. }\end{array}$ \\
\hline $\begin{array}{l}\text { Wagner, S.H., Parker, C.P., \& } \\
\text { Christianson, N.D. (2003) }\end{array}$ & $\begin{array}{l}\text { - Employees that think } \\
\text { and act like owners: } \\
\text { Effects of ownership } \\
\text { beliefs and behaviors } \\
\text { on organizational } \\
\text { effectiveness. }\end{array}$ & $\begin{array}{l}\text { - To develop a model of the psychological } \\
\text { experience of employee ownership } \\
\text { in work groups to investigate the } \\
\text { antecedents and consequences of } \\
\text { psychological ownership. }\end{array}$ & $\begin{array}{l}\text { - Quantitative } \\
\text { - Survey data } \\
\text { from two } \\
\text { questionnaires } \\
\text { - Organisational } \\
\text { records }\end{array}$ & $\begin{array}{l}\text { - Participation and a climate of self- determination } \\
\text { promote ownership beliefs. } \\
\text { - Ownership beliefs have positive relationships } \\
\text { with ownership behaviours and employees' } \\
\text { attitudes toward their organisations. } \\
\text { - Ownership behaviours have positive } \\
\text { relationships with the financial performance of } \\
\text { work groups. }\end{array}$ \\
\hline
\end{tabular}

Note: Please see the full reference list of the article, Olckers, C., \& Du Plessis, Y. (2012). The role of psychological ownership in retaining talent: A systematic literature review. SA Journal of Human Resource Management/SA Tydskrif vir Menslikehulpbronbestuur, 1O(2), Art. \#415, 18 pages. http://dx.doi.org/10.4102/sajhrm.v10i2.415

and competence. Therefore, psychological ownership of organisations consists, in part, of emotional attachments to them. It transcends merely cognitive evaluations of organisations.

\section{A multidimensional framework of psychological ownership}

Researchers have proposed several motivational models (Kanungo, 1982) to help predict employees' behaviour in organisations. Roodt (2004) proposed a motivational model based on a meta-theoretical analysis for explaining states of commitment. The authors adapted this model to develop a multidimensional framework of psychological ownership that distinguishes between the antecedents and consequences of psychological ownership. The authors prefer the term 'framework' to that of 'model' in this study because frameworks are untested, whereas researchers have proved empirically that models present phenomena in particular ways.

According to the framework the authors used here, salient needs, followed by salient values and then by salient goals, trigger employees' actions. Emotional (affective) and cognitive content influence these actions. Satisfying salient needs will lead to particular levels of psychological ownership that can result in either positive or negative behaviours. These behaviours then lead to particular outcomes for organisations.

Figure 1 illustrates the proposed multidimensional framework of psychological ownership.

It is important to note that psychological ownership has psychological theories of possession as its basis. In addition, according to Avey, Avolio, Crossley and Luthans (2009), one may associate psychological ownership with Positive Organisational Behaviour (POB). Luthans (2002, p. 59) defines $\mathrm{POB}$ 'as the study and application of positively oriented human resource strengths and psychological orientated practices that can be measured, developed, and effectively managed for performance improvement in today's workplace'.

According to Avey et al. (2009), psychological ownership has much in common with more widely recognised POB constructs and approaches like psychological capital (Luthans, Youssef \& Avolio, 2007), psychological well-being (Quick \& Quick, 2004; Wright, 2005), positive organisational scholarship (Cameron, Dutton \& Quinn, 2003) as well as character strengths and virtues (Peterson \& Seligman, 2004). All have positive orientations towards organisations and associations with accomplishment and success. Psychological ownership also meets the specific POB criteria that Luthans (2002) and Luthans et al. (2007) suggested because its basis is theory and research, one can measure it, it is open to change and development and affects the performance of organisations.

The authors discuss Roodt's (2004) proposed adapted model, which the authors used in their framework (see Figure 1) below.

\section{Needs}

Why do employees develop feelings of psychological ownership? What lies beneath this psychological condition? The answers lie in the motives or reasons for, or 'roots' of, psychological ownership. According to Pierce et al. (2001), psychological ownership exists because it satisfies three basic human needs: self-efficacy, self-identity, and having a home.

\subsection{Motives for, or the roots of, psychological ownership}

Pierce, Jussila and Cummings (2009) suggest that each of these motives facilitates the development of the state of psychological ownership, rather than being the direct cause of its occurrence. They add that if feelings of ownership have their roots in this set of motives, one can assume that employees could develop feelings of ownership for a variety of objects as long as they allow this set of motives to operate and to be satisfied. 


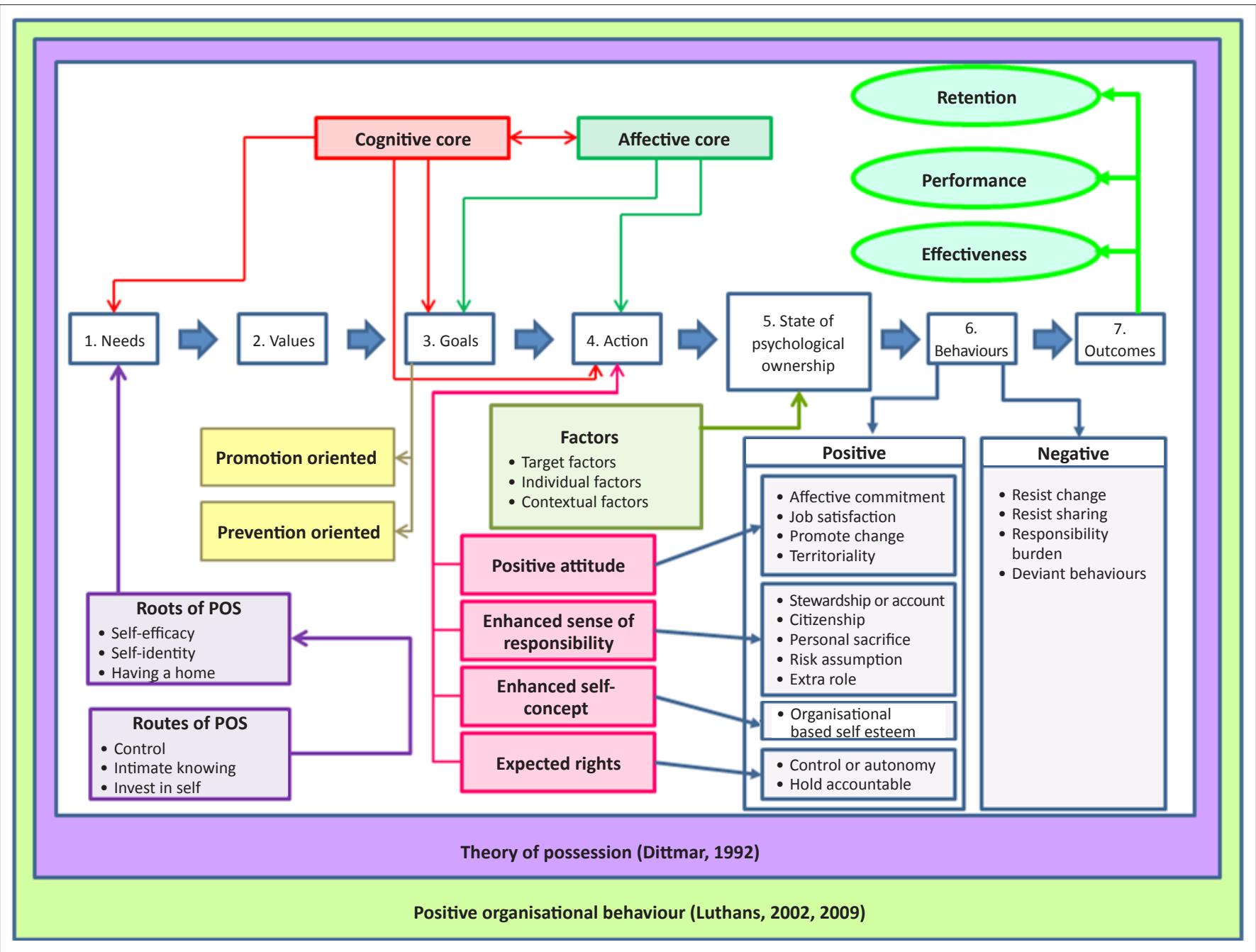

Source: Adapted from Olckers, C. (2011). A multi-dimensional measure of psychological ownership for South African organisations. Unpublished doctoral dissertation. University of Pretoria, Pretoria, South Africa

FIGURE 1: Multidimensional framework of psychological ownership.

The authors discuss each of the three motives for psychological ownership in detail.

\subsubsection{Self-efficacy}

According to Isaacs (1933), the motive that underlies possession is, in large part, a desire to be in control. According to Furby (1978), controlling objects through ownership produces pleasure and leads to perceptions of personal efficacy. Furby concludes that possessions become part of the extended self and are, therefore, important to employees because possessions help them to exercise control over the physical environment as well as over other employees.

\subsubsection{Self-identity}

The second motivation that underpins psychological ownership is the need for self-identity. Pierce et al. (2003) proposed that employees use ownership to define themselves, to express their self-identities to others and to maintain their continuity across time.

Employees experience pleasure and find comfort in their interactions with objects. Therefore, they internalise the socially shared meaning they ascribe to those objects and they become part of their self-identities (McCracken, 1986).

Dittmar (1992, p. 86) concludes that it is through our interactions with our possessions, coupled with reflections about their meaning, that 'our sense of identity, our selfdefinition, are established, maintained, reproduced and transformed'.

Rousseau (1998) notes that employees establish, maintain, reproduce and transform their self-identities by interacting with intangibles like organisations, missions or purposes. Therefore, it is important to ensure that all employees have well-defined goals and that they know exactly what their organisations expect of them.

\subsubsection{Having a home}

Having a 'home' in which to live is the third motive for feelings of ownership. According to Weil (1952, p. 41), having a place of one's own is an important 'need of the human soul'. Employees need to 'own' specific spaces.

Having a home or a place in which to live is a fundamental human need that goes beyond physical concerns and satisfies 
a pressing psychological need to belong (Porteous, 1976). One can best understand belongingness, in terms of psychological ownership in organisations, as feelings that employees belong in their organisations. According to Avey et al. (2009), when employees feel that they own their organisations, their 'having a place' meets their needs for belonging because it meets their social and socio-emotional needs. However, how can employees come to feel this ownership?

\subsection{Routes to psychological ownership}

Pierce et al. (2001) proposed that the phenomenon of psychological ownership has its roots in a set of human motives (self-efficacy, self-identity and having a home) and that employees can develop feelings of ownership for a variety of objects as long as the objects allow these motives to operate and to be satisfied. They examined how members of organisations come to feel ownership and identified three main routes through which psychological ownership emerges:

- controlling the targets (objects)

- getting to know the targets intimately

- investing in the targets.

Therefore, when employees exercise greater control, get to know the targets (organisations) intimately, and invest themselves in the targets of ownership, a sense of responsibility takes root and possessive feelings develop. Although the authors examined these routes separately, they could be interrelated.

The authors discuss these 'routes' to psychological ownership in more detail below.

\subsubsection{Controlling the ownership targets}

Control over objects gives rise to feelings of ownership of them (Furby, 1978; McClelland, 1951; Rochberg-Halton, 1984). Furby (1978) argues that the greater the amount of control employees can exercise over objects, the more they experience the objects psychologically as part of themselves. McClelland (1951) believes that employees begin to regard material objects that they can control as a part of themselves and that the greater the amount of control, the more they experience the objects as part of themselves.

According to Pierce et al. (2001), organisations can provide their members with numerous opportunities to exercise varying degrees of control over a number of factors, each of which is a potential target of psychological ownership. For example, job design is such a factor (Hackman \& Oldham, 1980; Kanungo, 1992). More complex tasks and jobs, which provide greater autonomy, imply higher levels of control and increase the likelihood that feelings of ownership of targets will emerge (Pierce et al., 2009). Conversely, some organisational factors, like centralisation and formalisation, decrease the possibility that employees can exert control. Therefore, these factors may impede the development of psychological ownership. In these situations, employees learn that nothing is 'theirs', because power vests in the structures and they have limited control over their organisations or any part of them (Pierce et al., 2001).

Researchers, like O'Driscoll and Beehr (2000), as well as Parker (1998), found that the extent to which employees believe that they have control is a key determinant of their effective responses like job satisfaction, work involvement and organisational commitment. Empirical evidence supports the relationship between autonomy and control, control and psychological ownership, as well as autonomy and psychological ownership (Pierce, O'Driscoll \& Coghlan, 2004; Tanaka \& Yamauchi, 2000; Yamauchi, Kumagai \& Kawasaki, 1999).

\subsubsection{Getting to know the targets intimately}

Beaglehole (1932) argues that intimate knowledge of objects, employees or places enables a union with them to occur. Sartre (1969 [1943]) posits that the more information employees have about, and the more knowledge they have of, objects, the deeper is the relationship between the objects and themselves and the stronger their feelings of ownership. Therefore, employees find themselves psychologically linked to things because of their active participation in, or association with, those things.

Pierce et al. (2001) propose that, by various processes of association, organisations can provide their members with a number of opportunities for getting to know potential targets of ownership like work, jobs, projects and teams. For example, when members of organisations receive information about possible organisational targets of ownership (like the missions of their organisations, their goals and performance), they tend to feel that they know their organisations better and may develop senses of psychological ownership of them. However, information alone may not be enough to create senses of ownership. The intensity of the associations, like the number of interactions between employees and their targets, also influences outcomes. Longer associations with targets (like long tenures) are more likely to lead to perceptions of knowing targets better and, as a result, to senses of ownership. Making information more accessible and less costly to acquire can also promote intimate knowledge.

\subsubsection{Investing in targets}

According to Durkheim (1957), employees own the objects they have created in much the same way that they own themselves. The investment of employees' energy, effort, time and attention in objects causes them to become one with the objects and to develop feelings that they own them (Rochberg-Halton, 1984).

Pierce et al. (2001) note that organisations provide a wealth of opportunities for their members to invest in different aspects of their organisations, like their jobs, projects, products, assignments or work teams, and therefore to feel ownership of those targets. According to Beaglehole (1932), workers can develop senses of ownership of their work, their machines and the products of their labour. The investment occurs in 
several forms, including investing employees' time, skills, ideas as well as their psychological, physical, and intellectual energies. As a result, employees may begin to feel that the target of ownership comes from them. Pierce et al. (2001) suggest that employees' psychological ownership of targets becomes stronger the more they invest in the targets.

Several activities in organisations may require different levels of self-investment. One can illustrate this by the example that follows. Non-routine technologies and jobs that are more complex allow employees to use their own judgement. They will then probably invest more of their own thoughts, personal styles and distinctive knowledge. Creating objects is one of the most apparent and powerful means through which employees invest in objects (Pierce et al., 2001). Creation involves investing one's values and identity as well as one's time and energy. Pierce et al. (2001) illustrate this by the examples that follow. Engineers may feel that they own the goods they design, politicians that they own the bills they write and entrepreneurs that they the organisations they establish. Academics may feel strong ownership of the outcomes of their academic pursuits.

\section{Values}

Pelham (1995) states that personal values make some objects more or less valued. Pierce et al. (2003) also claim that different attributes are important to different employees and that they seek different types of objects. To increase their self-concepts, employees may attempt to increase feelings of self-worth by striving to possess, psychologically or legally, the objects that hold the greatest importance for them. Ownership is one way of boosting employees' self-esteem, which is why they are probably likely to feel that they own the objects they consider most important according to their personal values.

Pierce et al. (2003) illustrate this with the example that follows:

... individuals whose perceptions of self-worth are predicated on intellect, or who are part of cultures that value intellect, may seek to feel ownership over targets that reinforce this attribute (e.g., books, pieces of art). (p. 20)

In contrast, it is possible that employees legally own some objects, yet never claim them as their own. This could be the case when the objects are not sources of efficacy and effectance and have no associations with the employees' selfidentities and/or the places in which they live, even though, according to Pierce et al. (2003, p. 20), they 'might have been earned with hard cash and is controlled and known'.

\section{Goals}

According to Liberman, Idson, Camacho and Higgens (1999), theorists distinguish between two important categories of desired goals: those that relate to advancement and growth and those that relate to safety and security. Therefore, employees have two self-regulatory systems that are concerned with acquiring either nurture or security. Employees' self-regulation in relation to their hopes and aspirations (ideals) satisfies their needs for nurture. Their goal is accomplishment and the regulatory focus is promotion. In contrast, employees' self-regulation of duties and obligations ('oughts') satisfies their security needs. Their goal is safety and their regulatory focus is prevention. Both promotion and prevention motivations are important for human survival. Therefore, the one approach is not necessarily more desirable than the other is. Avey et al. (2009) have applied these two approaches to examining psychological ownership. Therefore, psychological ownership takes two forms: promotion-orientated and prevention-orientated psychological ownership.

\section{Actions}

Positive attitudes towards targets, improved self-concepts and senses of responsibility are the three fundamental outcomes associated with feelings of possession (Furby, 1978). A 'bundle of rights' also frequently defines ownership. Ownership is associated with the right to information about the targets of ownership and the right to have a voice in decisions that affect employees. However, responsibility should balance all rights associated with ownership.

Van Dyne and Pierce (2004) suggest that this sense of possession, which allows employees to satisfy their basic needs for efficacy and effectance, self-identity and place, is a key to work-related attitudes, self-concepts, and behaviours. Therefore, psychological ownership has links with positive motivational, attitudinal and behavioural consequences.

\section{State of psychological ownership}

Several factors influence the emergence of psychological ownership. The potential for developing psychological ownership resides in both targets and employees and situational forces influence its emergence and manifestation.

\subsection{Target factors}

Pierce et al. (2001) suggest that targets must be visible and attractive to employees in order to capture their interest and attention. Targets must also have particular characteristics that fulfil the motives for efficacy and effectance, selfidentity, and/or the need for a place or home. Organisations could reveal their goals and expectations in their newsletters and display them in posters on notice boards in break rooms, display their mission statements at workstations and talk regularly to employees about them. This will have dual benefits: when organisations establish and monitor their goals, employees see visible achievements and feel that their organisations acknowledge and recognise them.

\subsection{Individual factors}

According to Pierce et al. (2003), there are differences in the strengths of the motives over time. Personality also has an effect. Winter, Steward, Klohen and Duncan (1998) point out that personality traits affect how employees express motives in their behaviour.

\subsection{Process factors}

Therefore, the processes through which psychological ownership emerge link to complex interactions between the 
'roots', the 'routes', target factors and individual factors. The three roots of psychological ownership (efficacy and effectance, identity and having a home) depend to some extent on each other. Ownership may emerge as the result of any one, or any subset of, these needs (Pierce et al., 2003). Similarly, the three routes to psychological ownership (control, intimate knowledge and self-investment) are complementary, additive and distinct. Any single route may result in feelings of ownership that are independent of the others.

\subsection{Contextual factors}

Although many contextual elements affect the emergence of psychological ownership, the focus in this review was on two aspects: structural and cultural aspects. The authors found that the structural aspects of the social context, like norms, rules, laws and hierarchies, might promote or prevent employees from developing feelings of ownership, whilst the cultural aspects of the social context also have a significant influence on the phenomenon of psychological ownership (Pierce et al., 2003).

Therefore, states of psychological ownership, whilst they could be latent in each employee, do not necessarily always occur and are not equally strong across employees, targets and situations. Complex interactions between a number of intra-individual, object-related and contextual factors determine psychological ownership.

\section{Behavioural consequences of psychological ownership}

Psychological ownership can result in either positive or negative behaviours. Psychological ownership has been associated with:

- greater commitment to organisations (VandeWalle, Van Dyne \& Kostova, 1995)

- greater accountability (VandeWalle et al., 1995)

- greater job satisfaction (Avey et al., 2009; Buchko, 1993; Mayhew, Ashkanasy, Bramble \& Gardner, 2007; Pierce et al., 1991; VandeWalle et al., 1995; Van Dyne \& Pierce, 2004)

- better organisational performance (Van Dyne \& Pierce, 2004; Wagner, Parker \& Christianson, 2003)

- better organisation-based self-esteem (Avey et al., 2009; VandeWalle et al., 1995; Van Dyne \& Pierce, 2004)

- more effort from employees to engage in organisational citizenship behaviours (Avey et al., 2009; VandeWalle et al., 1995; Van Dyne \& Pierce, 2004)

- increases in extra-role behaviour (VandeWalle et al., 1995): employees with higher levels of psychological ownership are more likely to engage in extra-role behaviours

- intentions to remain with organisations (Avey et al., 2009; Buchko, 1993).

Scholars like Dirks, Cummings and Pierce (1996) and Pierce et al. (2001) have also discussed the causal relationship between psychological ownership and resistance to organisational change, feelings of responsibility, willingness to take personal risks and make personal sacrifices. Unfortunately, psychological ownership could lead to other dysfunctional organisational behaviours. Deviant behaviours are other possible outcomes of psychological ownership that might lead to violations of organisational norms. However, according to Pierce et al. (2003), psychological ownership does not necessarily lead to dysfunctional behaviours, although it might lead to them in particular circumstances.

\section{Outcomes}

Employees' behaviour leads to particular outcomes for organisations. According to Bernstein (1979, p. 483), 'ownership instils a sense of pride in employees and acts as a motivator of greater performance'. Therefore, it is likely that ownership will encourage employees to think and behave like owners. This will improve the performance and effectiveness of organisations. Buchko (1993) maintains that ownership may influence employees' behaviours mainly through its effects on the intentions of employees to remain with their organisations (and retention from the organisations' points of view).

\section{Study objective 2: To distinguish psychological ownership from other work-related attitudes}

According to Pierce et al. (2001), the concept of psychological ownershipraisesquestionsaboutitsconceptualdistinctiveness because a number of constructs in organisational behaviour theory describe the psychological relationships that employees develop with their organisations. Morrow (1983) argued that it is important to distinguish between work-related attitudes (like organisational commitment, organisational identification, internalisation, psychological empowerment, job involvement and, in this case, psychological ownership) to avoid construct proliferation because all these attitudes involve a sense of attachment to, or resonance with, organisations.

Three constructs that are particularly interesting, when one considers psychological ownership, are organisational commitment, organisational identification and internalisation.

Organisational commitment refers to feelings and/or beliefs about why employees want to remain with particular organisations (Meyer \& Allen, 1991). Mael and Ashforth (1992) and Dutton, Dukerich and Harquil (1994) define organisational identification as a perceived oneness with an organisation and experience that organisation's successes and failures as one's own. Internalisation is the incorporation of values and assumptions with the self as guiding principles (Mael \& Ashforth, 1992).

Although commitment, identification and internalisation describe different types of psychological relationships with organisations, they could coexist with psychological ownership, especially when its targets are organisations (Pierce et al., 2001). Commitment, identification and internalisation are neither necessary nor sufficient conditions for psychological ownership. However, they are likely to have reciprocal relationships with it (Pierce et al., 2001). 
TABLE 3: Related constructs: Commitment, identification, psychological empowerment, internalisation and job involvement.

\begin{tabular}{|c|c|c|c|c|}
\hline Authors & Title & Purposes & Methods & Key findings \\
\hline \multicolumn{5}{|l|}{ Commitment } \\
\hline $\begin{array}{l}\text { Meyer, J.P., \& Allen, N.J. } \\
\text { (1991) }\end{array}$ & $\begin{array}{l}\text { - A three-component } \\
\text { conceptualization } \\
\text { of organizational } \\
\text { commitments. }\end{array}$ & $\begin{array}{l}\text { - To illustrate that organisational } \\
\text { commitment consists of three } \\
\text { components. }\end{array}$ & $\begin{array}{l}\text { - Qualitative } \\
\text { - Review of the } \\
\text { literature } \\
\text { - Development of } \\
\text { a model }\end{array}$ & $\begin{array}{l}\text { - The three components are: Affective } \\
\text { commitment (a desire), continuance } \\
\text { commitment (a need) and normative } \\
\text { commitment (an obligation) to maintain } \\
\text { employed by the organisation. } \\
\text { - The outcomes are: personal responsibility, low } \\
\text { turnover and better on-the-job behaviour, better } \\
\text { performance, less absenteeism, citizenship. }\end{array}$ \\
\hline Roodt, G. (2004) & $\begin{array}{l}\text { - Concept redundancy } \\
\text { and contamination in } \\
\text { employee commitment } \\
\text { research: Current } \\
\text { problems and future } \\
\text { directions. }\end{array}$ & $\begin{array}{l}\text { - To introduce the current state of } \\
\text { commitment research in five employee } \\
\text { commitment domains (commitment } \\
\text { terminology, research approaches, } \\
\text { research streams, research foci and } \\
\text { measures). } \\
\text { - To suggest the consequences of the } \\
\text { current state of affairs. } \\
\text { - To propose a solution for the current } \\
\text { state of affairs. }\end{array}$ & $\begin{array}{l}\text { - Qualitative } \\
\text { - Review of the } \\
\text { literature } \\
\text { - Presentation of } \\
\text { a model }\end{array}$ & $\begin{array}{l}\text { - A motivational approach as an integrating } \\
\text { mechanism on a meta-theoretical level is } \\
\text { presented to provide a sound theoretical } \\
\text { foundation for operationalising commitment as } \\
\text { a cognitive predisposition to work. } \\
\text { - This approach would address most causes of } \\
\text { concept redundancy and contamination and } \\
\text { would distinguish the state of commitment from } \\
\text { its antecedents and subsequent conditions. }\end{array}$ \\
\hline
\end{tabular}

\section{Identification} $\begin{array}{ll}\text { Dutton, J.E., Dukerich, J. } & \bullet \text { Organizational } \\ \text { M., \& Harquail, C. V. (1994) } & \text { images and member }\end{array}$ identification.

Edwards, M.R. (2005)

$$
\begin{aligned}
& \text { - Organisational } \\
& \text { identification: A } \\
& \text { conceptual and }
\end{aligned}
$$$$
\text { operational review. }
$$

\section{- To develop a model to explain how images of the person's work organisation shape the strength of the person's} identification with organisations.

\section{- To define Ol.}

- To determine how OI relates to OC.

\section{- Qualitative \\ Review of the \\ literature \\ - Opinions from \\ management \\ consultants \\ - Qualitative \\ - Review of the literature}

- Definition: When members incorporate the characteristics they attribute to their organisations with their self-concepts.

- The outcome of organisational identification (OI) is the intention to remain with organisations.

- There is an underlying bond between employees and their organisations.

- OC is a broader and more general construct than Ol, which has a more specific focus.

- The causes and outcomes of OI and OC are - The causes

- Involvement and intentions to remain are separate from the core identification construct. - The antecedents of OI are: What are organisations and what do they stand for. - The antecedents of OC are what do organisations do and how do they treat their employees?

- To propose a model of organisational identification. mater: A partial test of the reformulated model of organizational identification.

Rousseau, D.M. (1998)

- Why workers still identify with organisations.

Mael, F., \& Tetrick, L.E. (1992)

\section{- Identifying organisational} identification.

\section{Psychological empowerment} S. (2010)

Spreitzer, G.M. (1995)

$$
\begin{aligned}
& \text { - Psychological } \\
& \text { empowerment in the } \\
& \text { workplace: Dimensions, } \\
& \text { measurement and } \\
& \text { validation. }
\end{aligned}
$$

Psychological empowerment, job security and employe engagement. - To define identification and to describe
the antecedents and consequences of
identification.

\section{- To examine the uniqueness of organisational identification and to identify its distinctness from organisational commitment.}

- To examine the relationship between psychological empowerment, job security and employee engagement.

- To develop and validate multidimensional measure of psychological empowerment.
- Quantitative - Questionnaires - Self report data

- Organisational identification is perceived oneness with organisations.

- The consequences for organisations are support for them.

- Qualitative

of the literature

- Definition: employees perceive themselves as parts of the larger organisation.

- Identification is the driving force behind organisational performance, worker well-being and resilience in times of change.

- Quantitative

- Questionnaires

- Organisational identification is a subset of identification.

- Organisational identification is distinct from organisational commitment.

- Quantitative

- Questionnaires

- Self-reports

- Quantitative

Questionnaires

- Scale

development

- Psychological empowerment predicts employee engagement.

- Psychological empowerment interacts with - affective job insecurity to affect employee engagement.

- Definition: A motivational construct manifests in four cognitions: meaning competence, selfin four cognitions: meaning,

- Ietermination and effect. - Its anteced

control. - Its consequences are innovative behaviour and management effectiveness.

- Worker alienation is a relational and motivational construct.

- To examine the issue of worker alienation - Qualitative in the context of business ethics.

- Alienation and
empowerment: Some ethical imperatives in To suggest de-alienation measures in the Review of the literature
- 'Relational' refers to power sharing; motivational to a belief in self-determination and personal self-efficacy.

- Design jobs that provide task variety, personal relevance, autonomy and control, low levels of routines and rules and high advancement prospects.

Note: Please see the full reference list of the article, Olckers, C., \& Du Plessis, Y. (2012). The role of psychological ownership in retaining talent: A systematic literature review. SA Journal of Human Resource Management/SA Tydskrif vir Menslikehulpbronbestuur, 10(2), Art. \#415, 18 pages. http://dx.doi.org/10.4102/sajhrm.v10i2.415 
TABLE 3 (Continues...): Related constructs: Commitment, identification, psychological empowerment, internalisation and job involvement.

\begin{tabular}{|c|c|c|c|c|}
\hline Authors & Title & Purposes & Methods & Key findings \\
\hline \multicolumn{5}{|l|}{ Internalisation } \\
\hline $\begin{array}{l}\text { O'Reilly, C.E., \& Chatman, } \\
\text { J. (1986) }\end{array}$ & $\begin{array}{l}\text { - Organizational } \\
\text { commitment and } \\
\text { psychological } \\
\text { attachment. The } \\
\text { effects of compliance, } \\
\text { identification and } \\
\text { internalization on pro- } \\
\text { social behavior. }\end{array}$ & $\begin{array}{l}\text { - To investigate relationships between the } \\
\text { dimensions of commitment, prescribed } \\
\text { and extra-role activities. }\end{array}$ & $\begin{array}{l}\text { - Quantitative } \\
\text { - Questionnaires }\end{array}$ & $\begin{array}{l}\text { Definition of internalisation: Values of } \\
\text { employees and organisations are the same. } \\
\text { - Compliance, identification and internalisation } \\
\text { may predict psychological attachment. } \\
\text { - Identification and internalisation have positive } \\
\text { relationships with pro-social behaviours and } \\
\text { negative relationships with turnover. }\end{array}$ \\
\hline $\begin{array}{l}\text { Blau, G.J., \& Boal, K.B. } \\
\text { (1987) }\end{array}$ & $\begin{array}{l}\text { - Conceptualizing how } \\
\text { job involvement } \\
\text { and organizational } \\
\text { commitment affect } \\
\text { turnover and } \\
\text { absenteeism. }\end{array}$ & $\begin{array}{l}\text { - To illustrate how job involvement } \\
\text { and organisational commitment } \\
\text { could interact to affect turnover and } \\
\text { absenteeism. }\end{array}$ & $\begin{array}{l}\text { - Qualitative } \\
\text { - Literature } \\
\text { review }\end{array}$ & $\begin{array}{l}\text { - Job involvement is the extent to which } \\
\text { employees identify psychologically with their } \\
\text { jobs. } \\
\text { - Job involvement and organisational commitment } \\
\text { are related, but employees have distinct work } \\
\text { attitudes because of their different referents. } \\
\text { - Job involvement and organisational commitment } \\
\text { complement one another as predictors of } \\
\text { turnover and absenteeism. } \\
\text { - Job involvement seems to predict turnover more } \\
\text { consistently than absenteeism does. }\end{array}$ \\
\hline
\end{tabular}

Note: Please see the full reference list of the article, Olckers, C., \& Du Plessis, Y. (2012). The role of psychological ownership in retaining talent: A systematic literature review. SA Journal of Human Resource Management/SA Tydskrif vir Menslikehulpbronbestuur, 10(2), Art. \#415, 18 pages. http://dx.doi.org/10.4102/sajhrm.v10i2.415

Pierce et al. (2001) theorise that one can distinguish psychological ownership from other constructs on the basis of factors like its conceptual core (possessiveness), its focus, the motive it serves, its development, the type of state, the selected consequences as well as rights and responsibilities (see Table 4).

These notions undoubtedly share a number of similarities. However, the specifics of the different definitions suggest that the conceptual core differs from one concept to the next. Table 4 focuses primarily on the distinctiveness of psychological ownership and the other constructs rather than the similarities and links between them.

There may be overlaps between the observed effects of psychological ownership and those of other constructs. For example, theorists suggest that identification and psychological ownership both produce positive effects (like organisational citizenship behaviour) and negative effects (like deviance). However, the processes through which these effects occur are different. Commitment, identification and internalisation have references to the self in common. However, they differ in their theoretical anchoring. The concept of psychological ownership has its base in psychological theories of possession, whilst social identity theory is the basis of identification and social membership is the basis of commitment (Pierce et al., 2001). From Table 4, point 2 , it is clear that the question each of these constructs answers is different.

Therefore, feeling a sense of ownership of an organisation, feeling possessiveness and that the organisation is 'mine' or 'ours' differs fundamentally from the need, the desire or the obligation to remain with the organisation, that is, organisational commitment (Meyer \& Allen, 1991). Ownership differs from:

- using unique and admired characteristics of organisations to define the self or identify with them (Edwards, 2005; Mael \& Tetrick, 1992)

- association-based goal equivalence or internalisation (O’Reilly \& Chatman, 1986)
- feeling competent and intrinsically motivated at work, or psychological empowerment (Spreitzer, 1995; Stander \& Rothmann, 2010)

- being consumed by work and having work as the central life interest (Blau \& Boal, 1987; Hackett, Lapierre \& Hausdorf, 2001; Lawler \& Hall, 1970).

Therefore, Pierce et al. (2001) conclude that it is reasonable to suggest that psychological ownership may predict:

- certain effects that existing theoretical models of other constructs do not explain

- criterion variance that any of the other constructs currently do not explain.

Many studies confirm the existence of a construct like psychological ownership. Mayhew et al. (2007) and Avey et al. (2009) have shown that there is a strong association between affective organisational commitment and psychological ownership. Van Dyne and Pierce (2004) have provided discriminant validity evidence for the distinctiveness of psychological ownership items from the items they used to measure commitment, identification, internalisation, job satisfaction and involvement. Their observation of the unique ability of psychological ownership to predict worker attitudes and behaviours over and above the effects of demographic characteristics, affective organisational commitment, organisational identification, internalisation, job involvement and job satisfaction is important because it demonstrates the unique contribution of the psychology of possession to the understanding of relationships between employees and their organisations.

Olzer, Yilmaz and Ozler (2008) also found that psychological ownership variables account for $50.1 \%$ of changes in organisational commitment variables. VandeWalle et al. (1995) report that organisational commitment mediates the effects of psychological ownership on extra-role behaviour. Therefore, psychological ownership makes a difference, because possessive feelings about organisations (psychological ownership) lead to increases in organisational commitment. Committed employees are prepared to engage in extra-role behaviours (constructive work efforts that 
TABLE 4: Comparing psychological ownership to commitment, identification, internalisation, psychological empowerment and job involvement.

\begin{tabular}{|c|c|c|c|c|c|c|}
\hline $\begin{array}{l}\text { Dimensions of } \\
\text { distinctiveness }\end{array}$ & $\begin{array}{l}\text { Psychological } \\
\text { ownership }\end{array}$ & Commitment & Identification & Internalisation & $\begin{array}{l}\text { Psychological } \\
\text { empowerment }\end{array}$ & Job involvement \\
\hline 1. Conceptual core & Possessiveness & $\begin{array}{l}\text { Desire to remain } \\
\text { affiliated }\end{array}$ & $\begin{array}{l}\text { Use elements of } \\
\text { organisation's identity } \\
\text { to define oneself }\end{array}$ & $\begin{array}{l}\text { Shared goals or } \\
\text { values }\end{array}$ & $\begin{array}{l}\text { Achieve orientation to } \\
\text { work role }\end{array}$ & $\begin{array}{l}\text { Psychological identification } \\
\text { with one's job }\end{array}$ \\
\hline $\begin{array}{l}\text { 2.Questions of } \\
\text { employees }\end{array}$ & What do I feel is mine? & $\begin{array}{l}\text { Should I maintain } \\
\text { membership? }\end{array}$ & What am I? & $\begin{array}{l}\text { What do I } \\
\text { believe? }\end{array}$ & $\begin{array}{l}\text { Can I shape my work } \\
\text { role and context? }\end{array}$ & $\begin{array}{l}\text { How important is my job } \\
\text { to me? }\end{array}$ \\
\hline 3. Motivational bases & $\begin{array}{l}\text { - efficacy or effectance } \\
\text { - self-identity } \\
\text { - need for place. }\end{array}$ & $\begin{array}{l}\text { - security } \\
\text { - belongingness } \\
\text { - beliefs and } \\
\text { values. }\end{array}$ & $\begin{array}{l}\text { - attractions } \\
\text { - affiliation } \\
\text { - self-improvement } \\
\text { - holism. }\end{array}$ & $\begin{array}{l}\text { - need to be right } \\
\text { - beliefs and } \\
\text { values. }\end{array}$ & $\begin{array}{l}\text { - self-efficacy } \\
\text { - self-esteem } \\
\text { - access to information } \\
\text { (mission and } \\
\text { performance) } \\
\text { - rewards. }\end{array}$ & $\begin{array}{l}\text { - importance of work to } \\
\text { self-concept } \\
\text { - satisfy need for self- } \\
\text { esteem. }\end{array}$ \\
\hline 4. Development & $\begin{array}{l}\text { - Active imposition of } \\
\text { self on organisation }\end{array}$ & $\begin{array}{l}\text { - Decision to } \\
\text { maintain } \\
\text { membership }\end{array}$ & $\begin{array}{l}\text { - categorisation } \\
\text { of self with } \\
\text { organisation } \\
\text { - affiliation } \\
\text { - emulation. }\end{array}$ & $\begin{array}{l}\text { - Adoption of } \\
\text { organisation's } \\
\text { goals or values }\end{array}$ & $\begin{array}{l}\text { - value work in terms } \\
\text { of ideas and standards } \\
\text { - believe in competence } \\
\text { - autonomy } \\
\text { - effect on outcomes. }\end{array}$ & $\begin{array}{l}\text { - psychological importance } \\
\text { at work } \\
\text { - job situation is central to } \\
\text { people and their identities. }\end{array}$ \\
\hline 5. Type of state & - Affective or cognitive & - Affective & $\begin{array}{l}\text { - Cognitive or } \\
\text { perceptual }\end{array}$ & $\begin{array}{l}\text { - Cognitive or } \\
\text { objective }\end{array}$ & $\begin{array}{l}\text { - affective or perceptual } \\
\text { - cognitive. }\end{array}$ & $\begin{array}{l}\text { - affective or attitude } \\
\text { - self-perceived. }\end{array}$ \\
\hline 7. Rights & $\begin{array}{l}\text { - right to information } \\
\text { - right to voice. }\end{array}$ & - none & - none & - none & $\begin{array}{l}\text { - meaningful work } \\
\text { - access to information } \\
\text { - rewards } \\
\text { recognise } \\
\text { contributions of } \\
\text { people. }\end{array}$ & $\begin{array}{l}\text { - meaningful work } \\
\text { - adequacy of supervision. }\end{array}$ \\
\hline
\end{tabular}

Source: Pierce, J.L., Kostova, T., \& Dirks, K.T. (2001). Towards a theory of psychological ownership in organizations. Academy of Management Review, 26(2), 306 and researchers' own summary $\mathrm{OCB}$, organisation citizenship behaviour

benefit their organisations and go beyond the required work activities) and extra-role behaviours contribute to higher performance. Therefore, earlier research has shown that there is a relationship between extra-role behaviours and performance. Organisations that value organisational commitment and extra-role behaviours may want to increase the incidence of these behaviours by increasing psychological ownership.

\section{Study objective 3: To explore the role that psychological ownership could play in retaining skilled talent}

From the background to this study, it is clear that it is a challenge for organisations to keep their best and most talented staff.

Although some employees may try to sit out a downturn, the best are always employable and can go elsewhere. This creates a 'war for talent'. Kotzé and Roodt (2005) argue that the demand for, and difficulties in retaining, talent are challenges that are not unique to South African employers. However, they show that three additional factors compound them in South Africa.

Firstly, skilled people have emigrated and continue to do so at an astonishing rate. For example, according to Grant Thornton's 2008 International Business Report (IBR), 32\% of respondents, who took part in a survey amongst 300 privately-owned businesses that employed between 100 and 400 members of staff, confirmed that they had seriously considered leaving South Africa permanently ('Third of workers mull emigration', 2008). Secondly, there is a relative scarcity of specialist and managerial employees because of an over-supply of unskilled labour and an under-supply of skilled labour. Thirdly, the national drive to address employment equity has fuelled a war for talent amongst employees from designated groups.

Consequently, organisations need to consider how to keep their best employees - particularly given the huge costs they incur when valuable employees depart. Employees, who leave organisations, often take with them valuable knowledge and expertise they have gained through experience. In addition to these indirect costs, organisations may also face many costs that relate directly to turnover. They include exit interview time and administrative requirements, paying unused vacation leave, the cost of employing temporary workers or paying overtime for coworkers, which organisations ask to fill in, and training costs. Replacement costs include advertising, headhunting and selection fees. Training costs, both formal and informal, add to the overall burden (Mitchell, Holtom \& Lee, 2001). Losing good employees is also costly because of its effect on morale. The employees who remain often feel demotivated or disheartened. This causes decreased productivity and job satisfaction. If staff members see their colleagues snapping up new job opportunities, they could leave (Hay, 2002).

Kotzé and Roodt (2005) suggest that employers have two options to succeed in the war for talent. The first is to become 
TABLE 5: Talent retention

\begin{tabular}{|c|c|c|c|c|}
\hline Authors & Title & Purposes & Methods & Key findings \\
\hline \multicolumn{5}{|l|}{ Talent retention } \\
\hline $\begin{array}{l}\text { Birt, M., Wallis, T., \& } \\
\text { Winternitz, G. (2004) }\end{array}$ & $\begin{array}{l}\text { - Talent retention in a } \\
\text { changing workplace: } \\
\text { An investigation of } \\
\text { variables considered } \\
\text { important to South } \\
\text { African talent. }\end{array}$ & $\begin{array}{l}\text { - To determine the extent to which } \\
\text { extrinsic and intrinsic variables are } \\
\text { important to talented employees in the } \\
\text { South African context. }\end{array}$ & $\begin{array}{l}\text { - Quantitative } \\
\text { - Semi-structured } \\
\text { interviews } \\
\text { - Questionnaire }\end{array}$ & $\begin{array}{l}\text { - Both intrinsic and extrinsic variables are crucial. } \\
\text { - The five most important variables (challenging } \\
\text { and meaningful work, advancement } \\
\text { opportunities, high manager integrity and } \\
\text { quality, empowerment, and responsibility and } \\
\text { new opportunities) are all intrinsic in nature. } \\
\text { - The focus on intrinsic variables shows that } \\
\text { organisations' continued provision of these } \\
\text { variables is important in decisions to leave. }\end{array}$ \\
\hline $\begin{array}{l}\text { Bernthal, P.R., \& Wellins, } \\
\text { R.S. (2001) }\end{array}$ & $\begin{array}{l}\text { - Retaining talent: } \mathrm{A} \\
\text { benchmark study. }\end{array}$ & $\begin{array}{l}\text { - To examine the challenges that } \\
\text { organisations face in retaining employees } \\
\text { in an increasingly competitive labour } \\
\text { market. }\end{array}$ & $\begin{array}{l}\text { - Quantitative } \\
\text { - Questionnaires }\end{array}$ & $\begin{array}{l}\text { - Retention is an organisation's ability to keep the } \\
\text { employees it has already employed. } \\
\text { - The main things that influence employees to } \\
\text { leave relate to motivational fit (autonomy), } \\
\text { external rewards (recognition), cooperation } \\
\text { and trust, company direction (vision), home } \\
\text { life (work-life balance) and workplace discord } \\
\text { (politics and stress). }\end{array}$ \\
\hline $\begin{array}{l}\text { Kotzé, K., \& Roodt, G. } \\
(2005)\end{array}$ & $\begin{array}{l}\text { - Factors that influence } \\
\text { the retention of } \\
\text { managerial and } \\
\text { specialist staff: An } \\
\text { exploratory study of an } \\
\text { employee commitment } \\
\text { model. }\end{array}$ & $\begin{array}{l}\text { - To investigate the main factors that affect } \\
\text { the retention of managerial and specialist } \\
\text { staff, and whether there are retention } \\
\text { factor differences between demographic } \\
\text { groupings. }\end{array}$ & $\begin{array}{l}\text { - Quantitative } \\
\text { - Questionnaires }\end{array}$ & $\begin{array}{l}\text { - Factors that affect retention relate to } \\
\text { organisational commitment, employer of } \\
\text { choice perceptions, organisational climate and } \\
\text { employee well-being. } \\
\text { - There are differences between previously } \\
\text { disadvantaged employees and non- previously } \\
\text { disadvantaged employees, between men and } \\
\text { women, length of tenure and between age } \\
\text { groups. }\end{array}$ \\
\hline Hay, M. (2002) & $\begin{array}{l}\text { - Strategies for survival in } \\
\text { the war of talent. }\end{array}$ & $\begin{array}{l}\text { - To explore why employees change jobs } \\
\text { and identify how companies can retain } \\
\text { their best employees. }\end{array}$ & - Report & $\begin{array}{l}\text { - Employees leave because their organisations } \\
\text { do not develop their talents or skills; they are } \\
\text { unhappy with their bosses; there is a lack of } \\
\text { clear direction from managers; and there is no } \\
\text { scope for development. } \\
\text { - Organisations can assign new jobs, train } \\
\text { employees, remove low performers, ensure fair } \\
\text { treatment, give recognition, give freedom of } \\
\text { action and provide a challenging, varied role and } \\
\text { aim to become an 'employer of choice'. }\end{array}$ \\
\hline $\begin{array}{l}\text { Mitchell, T.R., Holtom, B.C., } \\
\text { \& Lee, T.W. (2001) }\end{array}$ & $\begin{array}{l}\text { - How to keep your best } \\
\text { employees: Developing } \\
\text { an effective retention } \\
\text { policy. }\end{array}$ & $\begin{array}{l}\text { - To explore how organisations can keep } \\
\text { their employees. }\end{array}$ & $\begin{array}{l}\text { - Quantitative } \\
\text { - Questionnaires }\end{array}$ & $\begin{array}{l}\text { - Employees stay because of their attachment } \\
\text { and fit. } \\
\text { - If employees like their jobs, are committed to } \\
\text { their organisations, and their organisations to } \\
\text { them, they will stay. } \\
\text { - Employees will stay if they feel embedded in } \\
\text { their jobs. }\end{array}$ \\
\hline $\begin{array}{l}\text { Kaye, B., \& Jordan-Evans, } \\
\text { S. (2002) }\end{array}$ & $\begin{array}{l}\text { - Retention in tough } \\
\text { times. }\end{array}$ & $\begin{array}{l}\text { - To explore the challenges that affect } \\
\text { organisations. } \\
\text { - To retain talent, present best practices for } \\
\text { building talent management systems. }\end{array}$ & $\begin{array}{l}\text { - Qualitative } \\
\text { - Discussion } \\
\text { groups }\end{array}$ & $\begin{array}{l}\text { - The challenges employers face are talent } \\
\text { shortages, mergers, reorganisation, high } \\
\text { turnover, low global unemployment, recruiting } \\
\text { costs, salary freezes and managing generations. } \\
\text { - Suggested practices are elevating retention to } \\
\text { a core business initiative, collecting retention } \\
\text { data, identifying talent retention drivers } \\
\text { by asking, holding managers accountable, } \\
\text { using comprehensive, effective strategies, } \\
\text { conducting retention workshops, building } \\
\text { career development into the core curriculum } \\
\text { and creating multidimensional mentoring } \\
\text { programmes. }\end{array}$ \\
\hline Cappelli, P. (2000) & $\begin{array}{l}\text { - A market-driven } \\
\text { approach to retaining } \\
\text { talent. }\end{array}$ & $\begin{array}{l}\text { - To determine how to target particular } \\
\text { employees. }\end{array}$ & $\begin{array}{l}\text { - Opinion from } \\
\text { management } \\
\text { consultant }\end{array}$ & $\begin{array}{l}\text { - Companies should look at compensation, } \\
\text { designing better jobs, tailoring jobs to the needs } \\
\text { of employees, encouraging the development of } \\
\text { social ties, look at their locations and employing } \\
\text { people they can train. }\end{array}$ \\
\hline Rankin, M.J. (2000) & $\begin{array}{l}\text { Winning the war for } \\
\text { talent: How to become } \\
\text { an employer of choice. }\end{array}$ & $\begin{array}{l}\text { - To determine how to become an } \\
\text { employer of choice. }\end{array}$ & $\begin{array}{l}\text { - Opinion from } \\
\text { management } \\
\text { consultant }\end{array}$ & $\begin{array}{l}\text { - Retention strategies include treating employees } \\
\text { as clients, balancing financial with emotional } \\
\text { needs, offering new challenges and building } \\
\text { training and development. } \\
\text { - Programmes into retention plans. }\end{array}$ \\
\hline \multicolumn{5}{|c|}{ Turnover intentions and psychological ownership } \\
\hline $\begin{array}{l}\text { Jeswani, S., \& Dave, S. } \\
\text { (2011) }\end{array}$ & $\begin{array}{l}\text { - Conceptual framework } \\
\text { on psychological } \\
\text { ownership as predictor } \\
\text { of turnover intentions. }\end{array}$ & $\begin{array}{l}\text { - To investigate and examine the various } \\
\text { predictors of psychological ownership } \\
\text { using an exhaustive literature review. } \\
\text { - To draw an outline of conceptual } \\
\text { research for further empirical testing to } \\
\text { predicate relationships between feelings } \\
\text { of ownership and employees' intention } \\
\text { to leave or stay. }\end{array}$ & $\begin{array}{l}\text { - Literature } \\
\text { review }\end{array}$ & $\begin{array}{l}\text { - Conceptualising psychological ownership may be } \\
\text { a foundation for a more systematic examination } \\
\text { of contextual factors. } \\
\text { - A wide variety of contextual elements will affect } \\
\text { the emergence of psychological ownership. } \\
\text { - The research discusses two main aspects: } \\
\text { Promotion-focused approaches and the } \\
\text { preventative-focused approaches. }\end{array}$ \\
\hline
\end{tabular}

Note: Please see the full reference list of the article, Olckers, C., \& Du Plessis, Y. (2012). The role of psychological ownership in retaining talent: A systematic literature review. SA Journal of Human Resource Management/SA Tydskrif vir Menslikehulpbronbestuur, 10(2), Art. \#415, 18 pages. http://dx.doi.org/10.4102/sajhrm.v10i2.415

and remain an 'employer of choice'. This will attract and retain employees with the profile they require (Cappelli, 2000). The second is to develop, retain and use their existing talent pool efficiently.
The second option is the preferred one in this study. Rossi (2000), who suggests that the best method of filling important vacancies is to ensure that current qualified employees remain, also recommends the second option. Organisations 
know their current employees. In addition, they are familiar with the internal workings of their organisations. They have already established the formal and informal networks they need to help them remain productive in their organisations and their organisations have trained them to use many of their methods and systems.

In the effort to win the war for talent, organisations have shifted their attention to determining the intrinsic and extrinsic reward variables that help them to retain talent. Previous studies, like those of Bernthal and Wellins (2001) as well as Cappelli (2000), have identified several intrinsic and extrinsic factors.

Different studies attach differing levels of importance to these factors. A study by Towers Perrin (HR Focus, 2003), for example, emphasises extrinsic rewards like performancebased pay. However, Kaye and Jordan-Evans (2002) report that, despite the importance of extrinsic variables, like compensation, for retaining talent, intrinsic factors, like having good supervisors, significant and challenging work and opportunities to develop are more important.

In a study on 745 employee responses to a retention survey that Bernthal and Wellins (2001) conducted, employees rated the retention factors that follow as very important:

- the quality of their relationships with supervisors or managers

- the ability to balance work and home life

- the level of cooperation with co-workers

- a clear understanding of work objectives

- the level of challenging work and autonomy - the freedom to direct work.

Jamrog (2004) explains:

The best people are not motivated by and do not stay for the money alone. They stay because they are engaged and challenged by work that makes them better at what they do. They want to work for more than just the pay check. (p. 11)

In his article 'Hunting for black executives', Bruce Whitfield (2007) observed that many South African companies struggle to retain upwardly-mobile black talent, even though companies under pressure to transform are prepared to pay large salaries to attract the right skills. However, although human resource directors acknowledge the importance of competitive salaries when it comes to attracting and retaining talented staff, they realise that 'it's not all about the money'.

Meyer and Allen (1991) observed that organisations that focus on intrinsically important variables benefit by eliciting greater affective commitment from their talented employees. Behaviours and attitudes, like strong beliefs in, and acceptance of, the values and goals of their organisations, the willingness to work hard to benefit their organisations and the desire to remain with their organisations, illustrate this. Birt, Wallis and Winternitz (2004) have found that organisations with high levels of employee commitment outperform those with low levels by $200 \%$. Rankin (2000) advises that focusing on intrinsic variables in order to increase commitment amongst talented employees seems to make good business sense.

Buchko (1993) found that ownership could influence employee behaviours, mainly through its effect on the intentions of employees to remain with their organisations. This effect is both direct and indirect. It operates through increased organisational commitment to tie employees to their organisations and decrease the effects of turnover. Consistent with much of the previous research on turnover (like that of Mobley, 1982), Buchko (1993) found that the intention to leave mediates the effects of commitment on turnover.

According to him, the direct and indirect effects of ownership are significant. In fact, previous research (French \& Rosenstein, 1984; Klein, 1987; Long, 1982) has suggested that the effects of attitudinal variables on ownership are strong enough to influence turnover independently of their effects on intentions to leave. In their study, Jeswani and Dave (2011) proposed a conceptual framework of psychological ownership as a predictor of intentions to leave. Avey et al. (2009) and Olckers (2011) found a positive relationship between psychological ownership and employees' intentions to remain with their organisations.

It seems clear that psychological ownership could affect the intentions of employees to remain with their organisations. Therefore, it can probably play a role in retaining talent.

\section{Discussion}

Here, the authors elaborate on the achievement of the three study objectives and the implications of psychological ownership for human resource practitioners and managers.

\section{Study objective 1}

The authors have achieved their first study objective: 'to explore and describe the concept of psychological ownership'.

Psychological ownership is 'that state where an individual feels as though the target of ownership or a piece of that target is "theirs"' (Pierce et al., 2003, p. 86). According to Pierce et al. (2001), employees can direct psychological ownership at several objects (including organisations, jobs or work projects). It is a sense of possessing objects where the objects become extensions of themselves and link closely to employees' identities (Pierce et al., 2001).

Therefore, this study determined that psychological ownership provides an answer to the question 'What do I feel is mine?'

Organisations can benefit from managing psychological ownership because, according to Pierce et al. (1991) and Mayhew et al. (2007), psychological ownership can motivate employees to perform at high levels and even inspire them to engage in extra-role behaviours. Beaglehole (1932) and Furby 
(1978) theorise that feelings of possession create a sense of responsibility that influences behaviour.

According to Hall (1966), feelings of responsibility include a responsibility to invest time and energy to advance the cause of organisations by being protective, caring and nurturing. When employees identify closely with their organisations, the desire to maintain, improve and protect that identity results in an improved sense of responsibility for work outputs (Kubzansky \& Druskat, 1993, cited in Pierce et al., 2003). According to Pierce et al. (2001), one can see several organisational effects, including stewardship, as responsibilities and as the products of psychological ownership. According to Rogers and Freundlich (1998), employees who feel that they own their organisations believe that they have the right to influence the directions of their organisations and that they have a 'deeper responsibility' than those who do not feel ownership.

According to Pierce et al. (2001), it is possible to facilitate the development of psychological ownership in organisations because organisations can satisfy the motives of psychological ownership (self-efficacy and effectance, self-identity and having a place), although managers cannot control these motives. However, managers can work on the so-called 'routes' to psychological ownership by organising work so that employees become more psychologically tied to the targets (like organisations) and the targets become extensions of themselves.

The authors finally achieved their first study objective by introducing a multidimensional framework of psychological ownership that distinguishes the antecedents from the consequences of psychological ownership because it links with positive behavioural and social-psychological consequences.

\section{Study objective 2}

The authors achieved their second study objective, which was 'to distinguish psychological ownership from other related constructs' by clearly indicating its distinctiveness.

It is important to pay attention to psychological ownership because it is conceptually distinct from organisational commitment, identification, internalisation, psychological empowerment and job involvement. It describes a unique aspect of the human experience in organisations. The particular ability of psychological ownership to predict worker attitudes and behaviours, over and above the effects of demographic characteristics, affective organisational commitment, organisational identification, internalisation, job involvement and job satisfaction, is important. It shows the unique contribution of the psychology of possession to understanding the individual-organisation relationship (Van Dyne \& Pierce, 2004).

Table 4 makes it clear that one can distinguish psychological ownership from other work-related constructs. These factors are its conceptual core (namely possessiveness), its focus, its motive, its development, its type of state, its selected consequences as well as rights and responsibilities.

\section{Study objective 3}

The authors also achieved their third study objective, which was 'to explore the role that psychological ownership could play retaining skilled talent'.

It is clear from the literature that it is a challenge for organisations to retain their most talented and skilled staff. Therefore, the managers in organisations are responsible for creating work environments that engage and retain employees. If organisations can develop and foster a sense of psychological ownership amongst employees by addressing the factors in the framework, they could become better workplaces where sustainable performance and retaining talent is not a problem but a competitive differentiator. Organisations can benefit from psychological ownership because it leads employees to feel responsible towards targets (like organisations) and to show stewardship. It can help organisations to retain talent and influence the intentions of skilled employees to remain with their organisations.

Therefore, it is clear that psychological ownership, which is a multidimensional construct, could help organisations to retain the talents of skilled employees.

\section{Conclusion}

This study determined that psychological ownership provides an answer to the question: 'What do I feel is mine?' If talented employees do not feel that parts of their organisations are theirs, they might not mind leaving. Traditional retention strategies, like benefits, incentives and development opportunities, will become ineffective. The pivotal role that psychological ownership plays is obvious. Human resource practitioners and managers must understand that they cannot always retain talent using tangible means. The intangible psychological phenomenon is also important and often ignored.

\section{Limitations of the study}

The construct of psychological ownership, like most social constructs, is complex. This might pose a limitation to the framework if it has omitted some variables. The researchers have done their best to be objective in developing the framework of psychological ownership and in considering the construct's relation to retaining talent. Nevertheless, some subjectivity is a possibility.

\section{Suggestions for future research}

The authors have made theoretical recommendations to increase psychological ownership in organisations. They have not ruled out the possibility of building onto the framework as a topic for future research because there could be other variables that apply in different contexts. 
The current environment calls for the development of a survey instrument that organisations can use to understand whether, and how, employees interpret their psychological ownership of their organisations and to help organisations to retain their most valuable employees.

Such an instrument should determine the extent to which employees (especially given their diversity) feel that they own their organisations, whether employees feel that they identify with them, have a sense of responsibility towards them and feel that they have some control over their work environments.

Furthermore, a study into the links between psychological ownership and attitudes to work in different generations could also be useful for retaining talent and could reveal possible differentiating factors.

\section{Acknowledgements}

The authors acknowledge Maureen Bashabe, who created an example of the design they used in this paper: Bashabe, M. (2010). Defining talent management: A review of the South African literature. Unpublished master's thesis. University of Johannesburg, Johannesburg.

\section{Competing interests}

The authors declare that they have no financial or personal relationship(s) that may have inappropriate influenced them when they wrote this paper.

\section{Authors' contributions}

The authors contributed equally to this article.

\section{References}

Arnold, J., \& Randall, R. (2010). Work psychology: Understanding human behaviour in the workplace. (5th edn.). Harlow, Essex: Pearson Education.

Avey, J.B., Avolio, B.J., Crossley, C.D., \& Luthans, F. (2009). Psychological ownership: Theoretical extensions, measurement and relation to work outcomes. Journal of Organizational Behavior, 30, 173-191. http://dx.doi.org/10.1002/job.583

Beaglehole, E. (1932). Property: A study in social psychology. New York: Macmillan.

Bernstein, P. (1979). Workplace democratization: Its internal dynamics. New Brunswick, NJ: Transaction Books.

Bernthal, P.R., \& Wellins, R.S. (2001). Retaining talent: A benchmarking study. HR Benchmark Group, 2(3), 1-28.

Birt, M., Wallis, T., \& Winternitz, G. (2004). Talent retention in a changing workplace: An investigation of variables considered important to South African talent. South African Journal of Business Management, 35(2), 25-31.

Blau, G.J., \& Boal, K.B. (1987). Conceptualizing how job involvement and organizational commitment affect turnover and absenteeism. Academy of Management Review, 12(2), 288-300. Retrieved March 16, 2011, from http://www.jstor.org/ stable/258536

Brown, T.L. (1989, 19 June). What will it take to win? Industry Week, p. 15

Buchko, A.A. (1993). The effects of employee ownership on employee attitudes: An integrated causal model and path analysis. Journal of Management Studies, 30(4), 633-657. http://dx.doi.org/10.1111/j.1467-6486.1993.tb00319.x

Cameron, K., Dutton, J., \& Quinn, R. (Eds.). (2003). Positive organizational scholarship. San Francisco: Berrett-Koehler.

Cappelli, P. (2000). A market-driven approach to retaining talent. Harvard Business Review, 78(1), 103-112.

De Villiers, R. (2006). Alumni talent: How losing the retention battle can help with the talent war. Civil Engineering: Magazine of the South African Institution of Civil Engineering, 14(1), 15.
Dirks, K.T., Cummings, L.L., \& Pierce, J.L. (1996). Psychological ownership in organizations: Conditions under which individuals promote and resist change. In R.W. Woodman \& W.A. Pasmore (Eds.), Research in organizational change and development (pp. 1-23). Greenwich, CT: JAl.
d.W.

Dittmar, H. (1992). The social psychology of material possessions: To have is to be. New York: St. Martin's.

Dunn, S., Richardson, R., \& Dewe, P. (1991). The impact of employee share ownership on worker attitudes: A longitudinal case study. Human Resource Management Journal, 1(1), 1-17. http://dx.doi.org/10.1111/j.1748-8583.1991.tb00227.x

Durkheim, E. (1957). Professional ethics and civil morals. (C. Brookfield, Trans.) London: Routledge and Kegan Paul.

Dutton, J.E., Dukerich, J.M., \& Harquil, C.V. (1994). Organizational images and member identification. Administrative Science Quarterly, 39, 239-263. Retrieved February 10, 2011, from http://www.jstor.org/stable/2393235

Edwards, M.R. (2005). Organizational identification: A conceptual and operational review. International Journal of Management Reviews, 7(4), 207-230. Article first published online: 23 Feb 2006, http://dx.doi.org/10.1111/j.14682370.2005.00114.x

Fiorito, J.D.P., Bozeman, A., Young, A., \& Meurs, J.A. (2007). Organizational commitment, human resource practices, and organisational characteristics. Journal of Managerial Issues 19(2), 186-207.

French, J.L., \& Rosenstein, J. (1984). Employee ownership, work attitudes, and power relationships. Academy of Management Journal, 27(4), 861-869. http://dx.doi. org $/ 10.2307 / 255883$

Furby, L. (1978). Possession in humans: An exploratory study of its meaning and motivation. Social Behaviour and Personality, 6(1), 49-65. http://dx.doi. org/10.2224/sbp.1978.6.1.49

Hackett, R.D., Lapierre, L.M., \& Hausdorf, P.A. (2001). Understanding the links between commitment constructs. Journal of Vocational Behavior, 58, 392-413. http://dx.doi.org/10.1006/jvbe.2000.1776

Hackman, J.R., \& Oldham, G.R. (1980). Work redesign. Reading, MA: Addison-Wesley. Hall, E.T. (1966). The hidden dimension. Garden City, NY: Doubleday.

Hay, M. (2002). Strategies for survival in the war of talent. Career Development International, 7(1), 52-55. http://dx.doi.org/10.1108/13620430210414883

HR Focus. (2003). Rewards: The not-so secret ingredient for managing talent. HR Focus, 80(1), 3-5.

Isaacs, S. (1933). Social development in young children. London: Routledge \& Kegan Paul.

Jamrog, J. (2004). The perfect storm: The future of retention and engagement. Tampa, FL: Human Resource Institute, University of Tampa, Florida.

Jeswani, S., \& Dave, S. (2011). Conceptual framework on psychological ownership as predictor of turnover intentions. KKIMRC International Journal of Research in Finance and Accounting 1(1), 52-70.

Kanungo, R.N. (1982). Work alienation: An integrative approach. New York: Praeger.

Kanungo, R.N. (1992). Alienation and empowerment: Some ethical imperatives in business. Journal of Business Ethics, 11(5), 413-422. Retrieved June 05, 2011, from http://www.jstor.org/stable/25072290

Kaye, B., \& Jordan-Evans, S. (2002). Retention in tough times. Training and Development, 56(1), 32-37.

Klein, K. (1987). Employee stock ownership and employee attitudes: A test of three models. Journal of Applied Psychology, 72(2), 319-332. http://dx.doi. org/10.1037/0021-9010.72.2.319, PMid:3583982

Kotzé, K., \& Roodt, G. (2005). Factors that affect the retention of managerial and specialist staff: An exploratory study of an employee commitment model. SA Journal of Human Resource Management/SA TydskrifvirMenslikehulpbronbestuur, $3(2), 48-55$.

Kruse, D. (1984). Employee ownership and employee attitudes: Two case studies. Norwood, PA: Norwood Editions.

Lawler, E.E., \& Hall, D.T. (1970). Relationship of job characteristics to job involvement, satisfaction and intrinsic motivational. Journal of Applied Psychology, 54(4), 305312. http://dx.doi.org/10.1037/h0029692

Liberman, N., Idson, L.C, Camacho, C.J., \& Higgins, T.E. (1999). Promotion and prevention choices between stability and change. Journal of Personality and Social Psychology, 77(6), 1135-1145. http://dx.doi.org/10.1037/0022-3514.77.6.1135, PMid:10626368

Long, R.J. (1982). Worker ownership and job attitudes: A field study. Industria Relations, 21(2), 196-215. http://dx.doi.org/10.1111/j.1468-232X.1982. tb00228.x

Luthans, F. (2002). The need for and meaning of positive behavior. Journal of Organizational Behavior, 23(6), 695-706. Retrieved October 15, 2010, from http://www.jstor.org/stable/4093649

Luthans, F., Youssef, C.M., \& Avolio, B.J. (2007). Psychological capital: Developing the human competitive edge. Oxford: Oxford University Press.

Mael, F., \& Ashforth, B.E. (1992). Alumni and their alma mater: A partial test of the reformulated model of organizational identification. Journal of Organizational Behavior, 13(2), 103-123. Retrieved October 15, 2010, from http://www.jstor. org/stable/2488176

Mael, F., \& Tetrick, L.E. (1992). Identifying organizational identification. Educational and Psychological Measurement, 52(4), 813-824. http://dx.doi. org/10.1177/0013164492052004002 
Mattila, J., \& Ikävalko, M. (2003). Participative strategy process in a professional organization and the concept of psychological ownership. Reykjavik, Iceland: organization and the concept of psychological ownership. Reykjavik,
Paper presented at the 17th Nordic Conference on Business Strategies.

Mayhew, M.G., Ashkanasy, N.M., Bramble, T., \& Gardner, J. (2007). A study of the antecedents and consequences of psychological ownership in organizational settings. Journal of Social Psychology, 147(5), 477-500.

McClelland, D. (1951). Personality. New York: Holt, Rinehart \& Winston.

McCracken, G. (1986). Culture and consumption: A theoretical account of the structure and movement of the cultural meaning of consumer goods. Journal of Consumer Research, 13(1), 71-84. Retrieved October 15, 2010, from http://www. jstor.org/stable/2489287

Meyer, J.P., \& Allen, N.J. (1991). A three-component conceptualization of organizational commitment. Human Resource Management Review, 1(1), 61-89.

Mitchell, T.R., Holtom, B.C., \& Lee, T.W. (2001). How to keep your best employees: Developing an effective retention policy. Academy of Management Executive, 15(4), 96-109.

Mobley, W.H. (1982). Employee turnover: Causes, consequences and control. Reading, MA: Addison-Wesley.

Morrow, P.C. (1983). Concept redundancy in organizational research: The case of work commitments. Academy of Management Review, 8(3), 486-500. Retrieved June 05, 2011, from http://www.jstor.org/stable/257837

O'Driscoll, M.P., \& Beehr, T. (2000). Moderating effects of perceived control and need for clarity on the relationship between role stressors and employee affection reactions. Journal of Social Psychology, 140(2), 151-159.

O'Driscoll, M.P., Pierce, J.L., \& Coghlan, A. (2006). The psychology of ownership: Work environment structure, organizational commitment, and citizenship behaviors. Group and Organizational Management, 31(3), 388-416.

Olckers, C. (2011). A multi-dimensional measure of psychological ownership for South African organisations. Unpublished doctoral dissertation, University of Pretoria, Pretoria, South Africa.

O'Neal, S. (2005). Total rewards and the future of work. Workspan, 48(1), 18-26.

O'Reilly, C.E., \& Chatman, J. (1986). Organizational commitment and psychological attachment. Journal of Applied Psychology, 71(3), 492-499.

O'Reilly, C.E. (2002). The wrong kind of ownership. Across the board, 39(5), 19-20.

Olzer, H., Yilmaz, A., \& Ozler, A. (2008). Psychological ownership: An empirical study on its antecedents and impacts upon organizational behaviors. Problems and Perspectives in Management, 6(3), 38-47.

Parker, S. (1998). Enhancing role-breadth self efficacy: The roles of job enrichment and other organizational interventions. Journal of Applied Psychology, 83, 835-852.

Pelham, B. (1995). Self-investment and self-esteem: Evidence for a Jamesian model of self-worth. Journal of Personality and Social Psychology, 69, 1141-1150.

Pendleton, A., Wilson, N., \& Wright, M. (1998). The perception and effects of share ownership: Empirical evidence from employee buy-outs. British Journal of Industrial Relations, 36(1), 99-123. http://dx.doi.org/10.1111/1467-8543.00082

Peterson, C., \& Seligman, M. (2004). Character strengths and virtues: A handbook and classification. New York: Oxford University Press.

Pierce, J.L., Jussila, I., \& Cummings, A. (2009). Psychological ownership within the job design context: Revision of the job characteristics model. Journal of Organizationa Behavior, 30(4), 477-496. http://dx.doi.org/10.1002/job.550

Pierce, J.L., Kostova, T., \& Dirks, K.T. (2001). Towards a theory of psychological ownership in organizations. Academy of Management Review, 26(2), 298-310. Retrieved n.d., from http://www.jstor.org/stable/259124

Pierce, J.L., Kostova, T., \& Dirks, K.T. (2003). The state of psychological ownership: Integrating and extending a century of research. Review of General Psychology, 7(1), 84-107.

Pierce, J.L., O'Driscoll, M.P., \& Coghlan, A.M. (2004). Work environment structure and psychological ownership: The mediating effects of control. Journal of Social Psychology, 144(5), 507-534.

Pierce, J.L., Rubenfield, S.A., \& Morgan, S. (1991). Employee ownership: A conceptual model of process and effects. Academy of Management Review, 16(1), 121-144. Retrieved October 05, 2009, from http://www.jstor.org/stable/258609

Porteous, J. (1976). Home: The territorial core. Geographical Review, 66(4), 383-390.

Quick, J.C., \& Quick, J.D. (2004). Health, happy, productive work: A leadership challenge. Organizational Dynamics, 33, 329-337.
Rankin, M.J. (2000). Winning the war for talent: How to become an employer of choice. Trusts and Estates, 139(4), 54-57.

Rich stay comfortably rich. (2008, September 02). Fin24.com. Retrieved October 16, 2010, from http://www.fin24.com/business/Rich-stay-comfortablyrich-20080902

Rochberg-Halton, E.W. (1984). Object relations, role models, and cultivation of the self. Environment and Behavior, 16(3), 335-368.

Rogers, L., \& Freundlich, F. (1998). Nothing measured, nothing gained. Employee Ownership Report, XVIII, No. 1. Oakland, CA: National Center for Employee Ownership. Retrieved October 20, 2009, from http://www.ownershipassociates. com

Roodt, G. (2004). Concept redundancy and contamination in employee commitment research: Current problems and future directions. SA Journal of Industrial Psychology/SA Tydskrif vir Bedryfsielkunde, 30(1), 82-90.

Rossi, J.F. (2000). Employee retention: Why do employees stay with a company? St. Joseph's College, New York, 471, 1-19.

Rousseau, D.M. (1998). Why workers still identify with organizations. Journal of Organizational Behavior, 19(3), 217-233. Retrieved October 16, 2010, from http://www.jstor.org/stable/3100169

Sartre, J.P. (1969 [1943]). Being and nothingness: A phenomenological essay on ontology. New York: Philosophical Library.

Spreitzer, G.M. (1995). Psychological empowerment in the workplace: Dimensions, measurement and validation. Academy of Management Journal, 38(5), 1442 1465. Retrieved October, 2010, from http://www.jstor.org/stable/256865

Stander, M., \& Rothmann, S. (2010). Psychological empowerment, job insecurity and employee engagement. SA Journal of Industrial Psychology/SA Tydskrif vir Bedryfsielkunde, 36(1). http://dx.doi.org/10.4102/sajip.v36i1.849

Tanaka, K., \& Yamauchi, H. (2000). Influence of autonomy on perceived control beliefs and self-regulated learning in Japanese undergraduate students. North American Journal of Psychology, 2(2), 255-273.

Third of workers mull emigration. (2008, May 20). Fin24.com. Retrieved February 10, 2011, from http:///www.fin24.com/Business/articles/default/display_print 10, 2011, from http:///wWw.fin24.cor
article.aspx?Articleld=1518-1786 2

Tranfield, D., Denyer, D., \& Smart, P. (2003). Towards a methodology for developing evidence-informed management knowledge by means of systematic review. British Journal of Management, 14(3), 207-222. http://dx.doi.org/10.1111/14678551.00375

Van Dyne, L., \& Pierce, J.L. (2004). Psychological ownership and feelings of possession: Three field studies predicting employee attitudes and organizational citizenship behaviors. Journal of Organizational Behavior, 25(4), 439-459. Retrieved October 21, 2010, from http://www.jstor.org/stable/4093721

VandeWalle, D., Van Dyne, L., \& Kostova, T. (1995). Psychological ownership: An empirical examination of its consequences. Group and Organization Management, 20(2), 210-226.

Wagner, S.H., Parker, C.P., \& Christianson, N.D. (2003). Employees that think and act like owners: Effects of ownership beliefs and behaviors on organizational effectiveness. Personnel Psychology, 56, 847-871. http://dx.doi.org/10.1111/j.1744-6570.2003. tb00242.x

Weil, S. (1952). The need for roots: Prelude to a declaration of duties toward mankind. London: Routledge \& Kegan Paul.

Whitfield, B. (2007, February 07). Hunting for black executives. Fin24.com. Retrieved February 10, 2011, from http://www.fin24.com/articles/Hunting

Wilpert, B. (1989). Property, ownership, and participation: On the growing contradictions between legal and psychological concepts. In R. Russel \& V. Rus (eds.), International handbook of participation in organizations: For the study of organizational democracy, co-operation, and self-management, Vol. 2 (pp. 149164). New York: Oxford University Press.

Winter, D., Steward, J.O., Klohen, E., \& Duncan, L. (1998). Traits and motives: Toward an integration of two traditions in personality research. Psychological Bulletin, 105, 230-250.

Wright, T.A. (2005). The role of 'happiness' in organizational research: Past, present, and future directions. In P.L. Perrewe \& D.C. Ganster (Eds.), Research in occupational stress and well-being, Vol. 4 (pp. 221-264). Amsterdam: JAI Press.

Yamauchi, H., Kumagai, Y., \& Kawasaki, Y. (1999). Perceived control, autonomy, and self-regulated learning strategies among Japanese high school students. Psychological Reports, 85, 779-798. 